\title{
Specificity of Buddhist Morality within the Framework of Vietnamese Culture
}

\author{
Le Thi Hong Phuong ${ }^{1, *}$ Mai K Da ${ }^{2, a}$ Sergei Nizhnikov ${ }^{3, b}$
}

\author{
${ }^{1}$ The Center for Contemporary Religious Studies, VNU University of Social Sciences and Humanities, Hanoi, Vietnam \\ ${ }^{2}$ Faculty of Philosophy, VNU University of Social Sciences and Humanities, Hanoi, Vietnam \\ ${ }^{3}$ Department History of Philosophy, Peoples' Friendship University of Russia (RUDN University), Moscow, Russia \\ aEmail: maikda@ussh.edu.vn \\ bEmail: nizhnikov-sa@rudn.ru \\ *Corresponding author. Email: lethihongphuong@mail.ru
}

\begin{abstract}
Buddhist morality has asserted a profound influence on the life of the Vietnamese people. Buddhism is one of the vital cultural resources of the Vietnamese nation (along with Taoism and Confucianism), which has been creating history together with it and has simultaneously become a condition for promoting national values in the present-day circumstances. Regarding Buddhism as a way of spiritual and moral improvement, the authors analyze the value-based elements of Buddhist morality, connecting them with the objective of creating the image of a modern Vietnamese endowed with spiritual and ethical merits. The authors reveal ethical specificity of Buddhism, which consists in the fact that this teaching does not aim to identify the true and the false by means of connecting morality with a set of metaphysical dogmas in order to subsequently deduce divine commandments and prohibitions from them. In its essence, Buddhism is existential, yet its humanism is non-metaphysical, as it is based on the concept of nirvana instead of that of a theistic Absolute. On the one hand, Buddhism acknowledges scientific rationality standards; on the other hand, it emphasizes moral and existential aspects of a modern Vietnamese's life. Such a combination is enormously relevant nowadays and complies with the objectives of current social development.
\end{abstract}

Keywords: Buddhist morality, Vietnamese culture, moral education, ideal person, anthropology, theism,

nirvana, spiritual

\section{INTRODUCTION}

Present-day Vietnamese society is entering a stage of active development involving rapid economic progress and quality achievements in many spheres of life. The process of modernization of the country demands not only the great efforts from public organizations, scientific and technical inventions, their pragmatic use, and implementing an active social policy, but also maximum moral support for this process. The process of industrialization and modernization of society in Vietnam will not succeed if it focuses on merely material and technical development without paying attention to man's ability to make responsible choices and behave ethically.

Market economy generates certain conditions for development of man and society, but it also causes

*The reported study was funded by RFBR and MOST according to the research project № 20-511-S52002 "Philosophy of Being Human as the Core of Interdisciplinary Research". negative consequences in the spheres of morality and lifestyle, completely reversing the scale of spiritual values [1]. According to a number of sociologists, it is an inevitable consequence of the transformation of the socio-economic development model. However, market economy is not the prime cause of praising individualism and a selfish lifestyle. The problem seems to be rooted in the lack of spiritual education. For a long while, Vietnamese society has been paying insufficient attention to moral education aspects. In this regard, the urgent issue is that professionalization should be related to moral education. One of the ways of strengthening man's spiritual life is returning to the search for rational factors which strengthen morality, including those from the sphere of religion. In the context of the above problem, we are interested in Buddhism as a philosophical and religious system existing in Vietnam since olden times, including its system of moral values that can help solve exigent problems of man's spiritual life in the conditions of the modern world [2]. 
In the changing historical situation, contemporary Buddhism is significantly different from the ancient one; however, many of its positive factors, especially the moral ones, remain significant, in particular, they cultivate kindness in people encouraging them to strive for higher humanistic values and help support and promote moral values and a highly moral lifestyle based on love for mankind and selflessness. On the one hand, Buddhism acknowledges scientific rationality standards; on the other hand, it emphasizes moral and existential aspects of a modern Vietnamese's life. Such a combination is enormously relevant nowadays and complies with the objectives of current social development.

\section{BUDDHIST MORALITY WITHIN THE FRAMEWORK OF VIETNAMESE CULTURE}

Buddhism gained ground in Vietnam approximately in the 2 nd century A.D. and quickly became a religion profoundly influencing the spiritual life of the Vietnamese people. It can easily be seen that there are many common issues between Buddhist ethics and national ethical standards. It was one of the powerful factors that determined integration of the religions with the traditional beliefs.

The notion of the spiritual is presented as spirit in Buddhism, in spite of denial of any substantiality of existence in it. Probably exactly due to this very denial, the spiritual is born as transcendental, i.e. nirvana. Buddhism massively uses the method of apophaticism, which can also be found in the Christian tradition. When formulating the definition of the Deity, PseudoDionysius the Areopagite writes, "in spite of the fact that it is the Cause of any existence, it does not exist itself, as it is beyond any existence" [3]. The notion of nirvana possesses the same characteristics. From understanding the spiritual as a spirit, corresponding ethics emerges, and contemplation of the beyond, impassivity, detachment, etc. become its virtues. A new ideal of holiness originates.

Another fact significant for many Eastern spiritual traditions should also be mentioned: Buddhism almost merges philosophical and religious revelation (the one regarding the Logos and the one regarding the Theos), especially with regard to the notion of nirvana. Therefore, attributing this doctrine only to religion or only to philosophy is complicated. As we analyze philosophizing by such major thinkers as Plato and Heidegger, we inevitably have to conclude that the central concepts of their systems also belong to two types of revelation simultaneously. These are the definitions of Good and Existence.

Pure consciousness in Buddhism can be regarded as a symbol of the spiritual, which replaces the theistic Absolute. Pure consciousness is an ideal especially profoundly worked at by the Eastern traditions. This is where the spiritual path is seen as the disidentification of consciousness with any of its available content attempting to capture the entire field of consciousness. Alienating the "non-self" from one's own self, man constantly becomes more profound, cognizing himself as something different. As a result of spiritual cognition practiced in that manner, consciousness becomes emancipated from any of its available content, and man's inner world is free from the tyranny of attractions, emotions, chaotic thoughts, etc. "In Christianity, this process is practiced by means of prayer or appeal to the transcendental. In the Eastern spiritual traditions, transcending is performed by meditation, purification of the self from the "non-self" [4]. Nirvana represents man's reaching maximum perfection, full projection of his essence, acquiring the true meaning of life, and achieving all potentialities. Such is the spiritual ideal where man's alienation from his own essence is eliminated.

In Eastern ethics in general, and in Buddhism in particular, the notions of good and evil have a relative value. The attitude towards human life is not merely manifested in relations with people and society, but it also depends on the universe. Thus, comprehending good, in its essence, implies achieving harmony of the body and soul with the universe. The desire to preserve life is the driving force of all the actions in the universe. Hence, complete happiness can be reached only in the state of harmony with the rationality of the universe. In Eastern culture, the rationality of the universe is referred to as the Tao, the highest criterion of value. Confucius regards social criteria and values, such as humaneness, as the Tao; to Lao Tzu, the Tao is the natural values and laws of nature. As to Buddhism, it accepts supernatural spiritual values, bodhi, enlightenment, as such a Tao. It can be hypothesized that these three ideals of the three great doctrines of the East are basically three manifestations of a single true nature: kindness (Confucianism), beauty (Taoism), and truth (Buddhism). They represent the spiritual archetype of the Eastern culture that can be found in their area. This is the immanent foundation of Eastern ethics in general and Buddhism in particular [5].

Within the framework of the "Three Religions" (Taoism, Confucianism, and Buddhism), a compromise between Buddhism, traditional beliefs, and national ethics was shaped in a natural way in both emotional and labor relations among the Vietnamese. The Vietnamese acknowledge the differences among the three religions, but they share a similarity in encouraging people to do good deeds [6]. Confucianism stimulates people to engage in moral self-improvement and pay attention to the organization of society which ensures order within it; Taoism teaches people to love life and care for their bodies and health; Buddhism affirms mercy, cares for the human soul, and teaches 
how to get rid of sufferings. In the process of its integration, Vietnamese Buddhism developed towards synthesis, and this development was expressed in the perception and creation of Thiền (Zen).

\section{BUDDHIST MORALITY AS A REGULATOR OF BEHAVIOR}

Buddhism can be regarded as a way of moral perfection [7]. The objective of this teaching is transformation of emotional and cognitive structures of each man's personality. As a result, people seek to overcome vices of life and simultaneously stop any actions which make the others suffer. Moral perfection, according to the Buddhist teaching, is achieved when the profound psychological roots ruling man (namely, greed, hatred, and delusion) are eradicated. Greed is the root of evil, as its influence provokes people into committing immoral acts [8].

The objective of Buddhism is also psychological to a certain extent. This objective is not merging with God or existing eternally in a certain imaginary world, but merely achieving satisfaction (non-action), getting rid of any forms of greed, hatred, and all illusions [9]. Buddhism acknowledges the value basis for distinguishing which human deeds are right and which are wrong, or what is moral and what is immoral. According to the non-theistic teaching of Buddhism, the value basis for moral judgments should be revealed on the basis of connection with human experience, not on metaphysical realities [10]. The more people think the more attention they pay to their experience and the more likely they are not to lose faith in the importance of morality. Caring for morality implies thinking about good and evil, happiness and unhappiness, and man's serenity or anxiety.

Buddhist morality is not a fixed dogma or an order to obey. The moral value of behavior or an action is based on compliance with a certain guiding ideal or concept. In Vietnamese Buddhism (apparently somewhat influenced by Taoism), this is the idea of balance, harmony. Hence, depending on the situation, one should act in such a way as to reach a more balanced and harmonious internal state.

From this perspective, Buddhism appropriately explains the true cause of sin and wrongdoings. Accordingly, evil is a misconception of the true and illusory "self". Misconceptions generate egoism; in its turn, egoism forces an individual to strive only for selfprofit, which has a negative impact on the harmony of the universe. Therefore, evil is the result of error. Yet the genuine intention (bodhi) is within the very soul of man [11]. It inspires man to turn to good without any orders from the outside. When man's soul and mind are embraced by the light (reach enlightenment), he ceases to do evil and seeks to do good things. According to
Buddhist teachings, in order to achieve this state, one should act selflessly, with a pure soul, repent, and meditate. The Vietnamese Mahāyāna, Zen (Thiền) Buddhism, which focuses on attaining nirvana within the soul of every person, is based on these ideas [12].

Buddhist ethics can be thought of in two dimensions: the relative one and the absolute one. In the relative terms, it is personal morality in relation to one's family, society, and all the living things. Buddhism advocates that family should primarily be guided by filial reverence for parents; in society, one should accept the will of the people as one's own will, and be guided by the idea of the "Great Unity" (Datong) in relation to all living creatures. At the absolute level, the utmost principle of ethics is spiritual harmony between man and the universe. This principle emphasizes that behavioral values consist in motivation, in man's soul. This principle is definitely similar to the categorical imperative of Kantian ethics [13]. If motivation is pure and selfless, an action is considered good, and vice versa. Hence, Buddhism emphasizes the need for purification of the soul: only in this case motivation will be pure. In Taoism, this is unity with the Tao, in ancient Greece, with the Logos (Heraclitus).

The ethical concept of Buddhism fulfills the function of a regulator of moral behavior. A system of rules was developed within it to fulfill this function. These rules include the "Five Precepts" and the "Ten Virtues". The "Five Precepts", namely, "do not kill, do not intoxicate, do not steal, do not commit adultery, do not lie" are most important. These "Five Buddhist Precepts" are the most relevant, and the "Ten Virtues" are the commandments guiding people to do good deeds [14]. These ethical standards are of utmost importance for the individual, the family, and the entire society, as they directly regulate moral behavior of people and society.

Vietnamese Buddhist ethics is based upon the theory of karma. The three karmas (that of the body, that of the speech, and that of the thoughts) determine whether human nature is good or bad, kind or evil. The three karmas ruling the body and the soul are exactly the outer shell of the true soul (true mind). The true soul (true knowledge) is the only supreme reality, both immanent and supernatural [15]. From the point of view of Buddhism, in existential life, an action is always a consequence of the previous action and, in its turn, is the cause of the following actions. This continuous chain of causes and effects generates a person - man's individuality. According to Buddhist teachings, a personality is considered to be completely dependent on the karmic cycle. Man is in the karmic chain of causes and effects and is in charge of his good and evil deeds [16]. Karma is an ethical category of Buddhism that has the greatest influence on the spiritual life of the Vietnamese. 
Alongside the idea of karma, other aspects of Buddhist ethics have had their impact on the spiritual life of the Vietnamese to varying degrees. Such concepts as compassion, commitment, selflessness, altruism, and filial reverence, were accepted by the Vietnamese as natural and became a substantial component of traditional morality. Obviously, Buddhist morality has had a profound impact on the life of the Vietnamese people. It is one of the cultural life resources of the nation, which has been creating history together with it, and at the same time it will become a provision for promoting national values in the modern environment.

\section{BUDDHIST MORALITY AND EDUCATION}

The objective of forming a new man in Vietnamese society is bringing up people who are both talented and at the same time highly moral as members of a civilized society. The Vietnamese idea of a talented and virtuous person has much in common with the Buddhist ideal of a person combining wisdom and compassion. During the process of industrialization and modernization of the country, the role of knowledge keeps increasing. Attention is primarily paid to intellectual and scientific progress to prepare high-level human resources for national development [17]. Buddhism also attaches a lot of importance to reason. Buddhism sees wisdom as a light helping people realize the truth of life and avoid ignorance.

The criteria of rationality and scientific methods are the force dominating modern people's lives. Undoubtedly, scientific rationality has brought essential material progress to mankind, yet it is unable to defeat the roots of immoral human behavior. According to Buddhist teaching, humanity can hardly achieve peace, harmony, and happiness unless evil in human behavior is eradicated.

Reason is very important, but Buddhism ranks it on a par with mercy and compassion. Compassion in Buddhism is empathy for the others' pain and eagerness to share it. In other words, mercy and compassion are a person's love for a person, a person's love for all the beings regardless of their class or status, the rich ones and the poor ones, the noble ones and the unknown ones, which is awakened by the Buddha in all the living things. It can be said that Buddhist ethics starts from compassion, but it is not limited to mercy yet is transformed into a policy of salvation - an intention to save people from the sea of suffering. Without this altruism, there would be no self-sacrifice for the others' happiness. In this connection, one can recall the words by F.M. Dostoevsky stating that compassion is "the most important and probably the only law of human existence". M. Scheler emphasizes that Buddhism was born out of compassion comprehended in a metaphysical way. Religious symbols are being destroyed, moral principles keep weakening, but if compassion for all the living things is alive in man's heart, he will never do evil. The feeling of compassion will not let man fall or turn his thought towards evil. Compassion is not pity or merely feeling distressed; it does not include egoism, yet it actively seeks to help one's neighbor. Nietzsche opposed compassion exactly as pity which humiliates man and suppresses his craving for life. Christianity is also based on compassion comprehended in a metaphysical manner: every believer shares compassion for Christ and feels crucified together with him. Compassionate love for man is especially powerful in Russian cultural and religious tradition; this is exactly what generates a feeling of guilt and repentance that purifies man's soul. Compassion is the essential law of social life, which is also profoundly considered in Vietnamese Buddhism.

Reason and compassion should go hand in hand as two important characteristics of an ideal man. Wisdom without compassion is dry insensible wisdom, while compassion without wisdom is blind compassion. Compassion and wisdom are like two wings of a bird which help it fly towards the sky. Modern Vietnamese have similar views, considering that both the brain and the heart are necessary. A developed civilized society is supposed to focus on both material and spiritual values, attaching great importance to morality. Without this balance, society can hardly achieve sustainable development. The worldview of the modern Vietnamese includes a Buddhist concept of an ideal man, which can contribute to the spiritual and moral education of the Vietnamese.

\section{CONCLUSION}

From the point of view of the Buddhist teaching, the problems of modern society can be explained as a result of isolating scientific knowledge and technical skills from ethical wisdom. The spread of greed and hatred at all levels in the modern worldview results in disunity, poverty, and despair. Lack of attention to upbringing and compassion for other people's pain reinforces conflicts and tension in society. Therefore, the Buddhist ideal of moral improvement is directly connected with modern people' social life [18]. Buddhism with its moral values will maintain and consolidate its role in the spiritual education of the modern Vietnamese if they are able to apply their current and positive aspects. In Buddhism, love and altruism serve as the basis of relations among people, and this is what Vietnamese society requires today - everything for the sake of people and for people [19]

The meaning of Buddhism for modern society is that this teaching does not aim to identify the true and the false by means of connecting morality with a set of metaphysical dogmas in order to subsequently deduce divine commandments and prohibitions from them [20]. 
In its essence, Buddhism is existential, yet its humanism is non-metaphysical, as it is based on the concept of nirvana instead of that of a theistic Absolute. The efforts of science to transform society by implementing material changes will yield no positive result unless they are associated with man's spiritual and moral development. Man not merely survives, but also seeks the meaning of life, striving to reach a moral ideal which is justified in a rational way. In this regard, Buddhism can grant a lot to modern people, including those who have lost their faith in traditional metaphysical and theistic concepts. It is no coincidence that this teaching increasingly gains popularity in Western culture.

\section{References}

[1] Thich Thanh Tuan, "Buddhist ethics in the process of integration and development" in Buddhist studies. No 5, 2012, p. 61 (Thích Thanh Tuấn, Đạo đức Phật giáo trong quá trình hội nhập và phát triển. Nghiên cứu Phật học. Số 5, 2012, tr. 61)

[2] Hoang Thi Lan, "Understanding some Buddhist ethical issues in Vietnamese society today in Studying Buddhism". No 2, 1997, p. 25 (Hoàng Thị Lan, Góp phần tìm hiểu một số vấn đề đạo đức Phật giáo trong xã hội Việt Nam hiện nay. Nghiên cứu Phật học. Số 2, 1997, tr. 25).

[3] Mystical Theology. Kiev, "Put k istine", 1991, p. 157.

[4] S.A. Nizhnikov, Spiritual Cognition in Philosophy of East and West. Monograph. Moscow, PFUR, 2009, p. 12.

[5] Le Huu Tuan, "The influence of Buddhism on Vietnamese traditional morality" in Buddhist studies. No 4, 1999, p. 10 (Lê Hữu Tuân, Anh hưởng của Phât giáo đôi với đạo đức truyền thống Việt Nam. Nghiên cứu Phật học. Số 4, 1999, tr. 10).

[6] Thich Thanh Tuan, "Buddhist ethics in the process of integration and development" in Buddhist studies. No 5, 2012, p. 61 (Thích Thanh Tuấn, Đạo đức Phật giáo trong quá trình hội nhập và phát triển. Nghiên cứu Phật học. Số 5, 2012, tr. 61).

[7] Dang Thi Lan, "Buddhistic morality and Vietnam's traditional morality" in VNU Social Sciences and Humanitis. T. XVIII, No 2, 2002, p. 52 (Đặng Thị Lan, Đạo đức Phật giáo với đạo đức truyền thông Việt Nam. Tạp chí khoa học Đại học Quốc gia Hà Nội. Chuyên san Khoa học Xã hội và Nhân văn. T. XVIII., Số 2, 2002, Tr. 52)

[8] Hoang Thi Tho, "Ethical values of Buddhism in tradition and modernity" in Vietnam Studies - Proceedings of the Second International Conference. Hanoi: "Hanoi National University", 2018, pp. 353-354 (Hoàng Thị Thơ,"Giá trị đạo đức của Phật giáo trong truyền thống và hiện đaì”. Việt Nam hoc - Kỷ yếu Hội thảo Quốc tế lần thứ hai. Hà Nội: Đại học Quốc gia Hà Nội, 2018. Tr. 353-354).

[9] P.H. Premasiri, "Buddhist ethics, perfection of morality, and modern society" in Buddhist Culture. No 10, 2015, pp. 18-19 (P.H. Premasiri, Đạo đức Phật giáo, sự hoàn thiện về đạo đức và xã hội hiện đại. Văn hóa Phật giáo. Số 10, 2015,tr. 18-19)

[10] Ibid., p. 19.

[11] Ta Chi Hong, "Conception of justice, equality and tolerance Features of Buddhist ethics" in Buddhist studies. No 4, 2008, p. 33 (Tạ Chí Hồng, Một trong những nét đặc sắc của đạo đức Phật giáo là quan niệm về lẽ công bằng, bình đẳng và lòng khoan dung. Nghiên cứu Phật học. Số 4, 2008, tr. 33)

[12] Le Huu Tuan, "The influence of Buddhism on Vietnamese traditional morality" in Buddhist studies. No 4, 1999, p. 10 (Lê
Hữu Tuấn, Ảnh hưởng của Phật giáo đối với đạo đức truyền thống Việt Nam. Nghiên cứu Phật học. Số 4, 1999, tr. 11)

[13] S. Nizhnikov, "Foundations of ethics and education in philosophy of transcendentalism" in Proceedings of the International Conference on Arts, Design and Contemporary Education (ICADCE 2018). Paris: Atlantis Press, 2018, p. 604.

[14] Thich Gia Quang, "The value of Buddhist ethics in today's social life" in Buddhist studies. No 5, 2016, pp. 34-37 (Thích Gia Quang, Giá trị của đạo đức Phật giáo trong đời sống xã hội hiện nay. Nghiên cứu Phật học. Số 5, 2016, tr. 34-37).

[15] Le Huu Tuan, "The influence of Buddhism on Vietnamese traditional morality" in Buddhist studies. No 4, 1999, p. 10 (Lê Hữu Tuấn, Ảnh hưởng của Phật giáo đối với đạo đức truyền thống Việt Nam. Nghiên cứu Phật học. Số 4, 1999, tr. 10).

[16] Hoang Thi Tho, "Ethical values of Buddhism in tradition and modernity" in Vietnam Studies - Proceedings of the Second International Conference. Hanoi: Hanoi National University, 2018, p. 355 (Hoàng Thị Thơ, Giá trị đạo đức của Phật giáo trong truyền thống và hiện đại. Việt Nam học - Kỷ yếu Hội thảo Quốc tế lần thứ hai. Hà Nội: Đại học Quốc gia Hà Nội, 2018,tr. 355)

[17] Vo Van Dung, "Contribution of Buddhist ethics in youth education" in Buddhist studies. No 3, 2016, pp. 30-32 (Võ Văn Dũng, Đóng góp của đạo đức Phật giáo trong việc giáo dục đoàn viên thanh niên. Nghiên cứu Phật học. Số 3, 2016, tr. 3032).

[18] P.H. Premasiri, "Buddhist ethics, perfection of morality, and modern society" in Buddhist Culture. No 10, 2015, p. 18 (P.H. Premasiri, Đạo đức Phật giáo, sự hoàn thiện về đạo đức và xã hội hiện đại. Văn hóa Phật giáo. Số 10, 2015, tr. 18)

[19] Dang Thi Lan, "Buddhistic morality and Vietnam's traditional morality" in VNU Social Sciences and Humanities. T. XVIII No 2, 2002, p. 54 (Đặng Thị Lan, Đạo đức Phật giáo với đạo đức truyền thống Việt Nam. Tạp chí khoa học Đại học Quốc gia Hà Nội. Chuyên san Khoa học Xã hội và Nhân văn. T. XVIII, Số 2, 2002, tr. 54).

[20] P.H. Premasiri, "Buddhist ethics, perfection of morality, and modern society" in Buddhist Culture (Buddiiskaya kultura). No 10, 2015, pp. 18-19. (P.H. Premasiri, Đạo đức Phật giáo, sự hoàn thiện về đạo đức và xã hội hiện đại. Văn hóa Phật giáo. Số 10, 2015,tr. 19). 